\title{
The Experience of Nurse Faculty Members Enrolled in Doctoral Study
}

\author{
Carolyn J. Lee \\ University of Toledo, Toledo, Ohio, USA
}

carolyn.lee@utoledo.edu

\begin{abstract}
The focus of this paper is to describe the results of a study that examined the experience of nurse faculty members pursuing a doctoral degree. Influential factors in the student experience are identified from the student perspective and student recommendations for supportive practices are shared. Two hundred and seventy-seven nurses participated in a web-based survey. Participants described the rewards and challenges inherent in graduate study. Key enhancing and detracting factors were career goals and multiple life responsibilities, respectively. Primary recommendations for workplace support were adjustments in role responsibilities. The key recommendation to doctoral programs was for student centered program and course planning. This study contributes to our understanding of the doctoral student experience and can serve to guide the development of quality practices.
\end{abstract}

Key words: graduate study, doctoral student, student experience, nurse faculty, student support

[NOTE: This paper uses the U.S. definition of the term "faculty" as a group of teachers and instructors within a teaching institution rather than a particular division within a university.]

\section{Introduction}

The health care system relies on quality nursing education to prepare excellent nurses. In turn, the development and delivery of adequate nursing education depends on expert nurse faculty. Increasing the ranks of nurse faculty members holding the terminal degree is a pressing and international need in professional nursing education (American Association of Colleges of Nursing [AACN], 2003; Canadian Nurses Association, 2006; International Council of Nurses, 2006). Current factors contributing to the nurse faculty member shortage include the intersection of faculty age and retirements with lack of incoming faculty, age of doctoral recipients and time to degree, salary differentials with clinical practice, financial burden of graduate study and faculty role expectations (AACN, 2005).

In 2003, The American Association of Colleges of Nursing (AACN) argued that "the doctoral degree should be considered the appropriate and desired credential for a career as a nurse educa-

Material published as part of this publication, either on-line or in print, is copyrighted by the Informing Science Institute. Permission to make digital or paper copy of part or all of these works for personal or classroom use is granted without fee provided that the copies are not made or distributed for profit or commercial advantage AND that copies 1) bear this notice in full and 2) give the full citation on the first page. It is permissible to abstract these works so long as credit is given. To copy in all other cases or to republish or to post on a server or to redistribute to lists requires specific permission and payment of a fee. Contact Publisher@InformingScience.org to request redistribution permission. tor" (AACN, p. 3). The call for the international nursing community to expect a research or clinical doctoral degree to advance nursing science, practice, and education is consistent with other professional fields (Fitzpatrick, 2003).

As a practice discipline, it is more typical than not that nurses begin their careers in the practice setting, often for a number of years, before pursuing the 
doctoral degree. Higher practice salaries without the requirement of the terminal degree create true competition in trying to attract nurses to the career path of educator. Nationally, the median age of a doctoral degree recipient is 33.3 years while the median age of a nurse graduating with the terminal degree is 46.2 years (National Center for Education Statistics, 2004). This can often be attributed to the time spent in clinical practice prior to the start of an academic career. While students reap the benefits of clinically expert faculty members, the later entry into academe and pursuit of the doctorate by nurse educators poses unique concerns. This delay reduces the number of productive years that nurse scholars can contribute to advance the profession, nursing education, and the provision of health care at local, national, and global levels.

As the expectation for doctoral preparation is more widely adopted, non-doctoral prepared faculty experience the combined demands of faculty, life and doctoral student roles. The purpose of this study was, in part, to describe the experience of nurse faculty enrolled in doctoral programs, to appreciate enhancing and detracting factors in the student experience, and to identify student recommendations for supportive practices. Study findings examining the intersection of doctoral student and caregiver roles are described elsewhere (Lee, 2009).

\section{Literature Review}

Earning a doctoral degree is a unique educational endeavor. Golde (2006, p.5) described the aims of doctoral education to develop stewards of the discipline who serve to conserve ideas, develop new knowledge, and engage in scholarly efforts. Doctoral study includes socialization to new roles, integration of discipline norms, relationship building, and transformation of professional identity (Golde, 1998; Weidman, Twale \& Stein, 2001).

Each stage of the doctoral student journey presents unique opportunities and challenges. Movement along the trajectory of course work, qualifying examinations, candidacy, and the dissertation creates new circumstances and relationships. Generally, doctoral program attrition rates are estimated at $40-50 \%$ (Council of Graduate Schools, 2008). Attrition rates vary among disciplines and, because nurses pursue doctoral degrees in a number of fields, it is difficult to pinpoint their attrition rate. Institutional factors that can influence student attrition rates include quality of mentoring, institutional culture, and program environment (Council of Graduate Schools, 2008). A need exists to support students through phases of transition in doctoral study and to both anticipate and ease the student experience of social isolation in order to decrease attrition rates (Ali \& Kohun, 2007). Sweitzer (2009) argues that multiple social and developmental networks are influential in the doctoral student experience. The historical identification of faculty and advisors as the major influences on students negates the complexity of student lives, particularly as student populations become more diverse.

Challenges encountered by doctoral students include personal issues such as financial concerns, time demands, and the effect of school on social relationships. Student concerns include the quality of student and faculty relationships, mentorship needs, insecurities about academic capabilities, and negotiating the spoken and unspoken norms of the discipline or department (Anderson \& Swazey, 1998; Appel \& Dahlgren, 2003; Austin, 2002; Golde, 1998; Kerlin, 1995; Seagram, Gould \& Pyke, 1998; Weidman \& Stein, 2003). Doctoral study has been described as a multidimensional and transformative process of personal and professional growth for nurses (Heinrich, 2000; Heinrich, Rogers, Haley, \& Taylor, 1997; Kenty, 1995). Researchers have described the struggle of nurse doctoral students to juggle multiple roles, balance many tasks, and maintain the focus and discipline to persevere in their efforts (Colombraro, 1999; Jarnagin, 2005; Kenty, 1995).

The nursing literature identifies that role strain exists for both experienced and novice nurse faculty including lack of role preparation, coping with multiple work expectations, and conflict be- 
tween work and personal roles as sources of stress (Gormley, 2003; Siler \& Kleiner, 2001; Young, 1999). Steeped in nursing knowledge and the norms of clinical practice, nurses beginning an academic career must adapt to the cultural norms of academe. Adapting to the multiple tasks of teaching, research, scholarship, and service in the absence of strong mentoring can create an experience of dissonance for new nurse faculty (Schriner, 2007). The addition of doctoral study is an extra demand for those still adapting to a significant career adjustment. Salary may be a special determinant as prospective doctoral students wonder if the demands of doctoral study are worth it given the ready availability of well-paid master's level nursing positions (AACN, 2003, p. 8).

Curtis noted, "By its nature, academic work is potentially boundless" (2004, p. 21). Faculty work is a dynamic process of constant adaptation to new knowledge, approaches, and standards. The triad of teaching, scholarship, and service represent key dimensions of academic work. Statements from a number of organizations endorse the value and standards of these categories of faculty work. One example, The Statement on Professional Ethics, developed by The American Association of University Professors, affirms the obligations of academic professionals to be effective teachers, to advance their expertise as scholars, and to encourage the pursuit of knowledge by students and peers (American Association of University Professors [AAUP], 1987). The classic work of Boyer, Scholarship Reconsidered: Priorities of the Professoriate, is valuable in representing four domains of scholarship of value in the ideal academic setting (Boyer, 1990). The ways in which contemporary faculty can contribute to their discipline, institution, and community are represented in the multiple forms of scholarship endorsed by Boyer - discovery, integration, application, and teaching. These categories provide a framework for faculty evaluation, promotion, and tenure in many higher education institutions. For nurse faculty, clinical practice as a means to maintain competence, create scholarship, and meet certification expectations adds an additional expectation (Blair, Dennehy \& White, 2005; National Organization of Nurse Practitioner Faculties, 2005). Recent literature also documents increased attention to the demands of an academic career and the achievement of work-life balance, particularly meeting role expectations while integrating family life tasks as parent and caregiver to others (American Association of University Professors, 2001; Cole \& Curtis, 2004; Mason \& Goulden, 2004; Ward \& WolfWendel, 2004).

In summary, the literature documents the challenges of faculty work and graduate study. Those embarking on doctoral study must meet multiple demands in professional, life and student roles. Role strain can occur for some doctoral students adapting to new norms and expectations of doctoral study. Role strain can also occur for those still in transition to an academic career in nursing education. The current need for doctoral-prepared nurse educators compels an interest in research to examine the unique experience of nurse faculty doctoral students.

\section{Method}

\section{Design}

A web-based survey served as the research approach for this study which was conducted in 2006. Advantages of electronic surveys include eliminating paper and postage costs, efficiency in participation, and data entry costs (Dillman, 2000; Houtkoop-Steenstra, 2000; Fawcett \& Buhle, 1995). Refinement of the survey followed a review by expert faculty and nurse faculty recently or currently enrolled in doctoral study. The 32-item survey included multiple choice responses and text responses to allow participants to describe the student experience, to indicate enhancing and detracting factors, and to suggest supportive workplace and program practices. A copy of the survey can be found in the Appendix. 


\section{Participants}

All study participants held a faculty position in a member school of The Association of Colleges of Nursing in the United States and were simultaneously enrolled in a doctoral program in nursing or a discipline related to their professional role. Program deans supported the study by forwarding an electronic mail letter to nurse faculty enrolled in doctoral study. Direct survey access via an imbedded link in an electronic mail letter supported ease of participation. The e-mail letter provided information about the approved study and stated that participation was voluntary and implied consent and that no identifying information would be available to the researcher.

\section{Data Analysis}

It is important that qualitative survey answers be interpreted as descriptions and explanations of the experience of participants rather than as quantified data (Pope, Ziebland, \& Mays, 2000). In this study, hand coding of text responses served to extract key words and phrases in participant responses. The intent of content analysis, through reading and re-reading and the use of a color coding system, was to use the actual words of participants to illustrate the nurse faculty doctoral student experience, their perspective on influential factors, and their recommendations for supportive practices.

\section{Results}

Study participants were garnered through electronic mail communication with all nursing program deans of AACN-member nursing programs in the United States. Program deans identified to the researcher a total of 435 faculty members enrolled as doctoral students. It is possible that some deans forwarded the e-mail without identifying faculty numbers to the researcher. For this reason, it is not possible to identify an exact response rate. Two hundred and seventy-seven nurse faculty doctoral students employed in nursing schools across the United States responded to the survey, although not all participants answered all survey items.

Study participants were experienced professionals with $75 \%$ of participants being a nurse for more than 20 years. Full-time faculty appointments in a nursing school were held by $88.8 \%$ of participants and $51 \%$ of participants were enrolled as full-time graduate students. Sixty-nine percent of participants were enrolled in a nursing doctoral program while $29 \%$ identified other majors, such as higher education, educational leadership, or administration. Important student variables were that $71 \%$ of participants were half-way or farther in their program and $49 \%$ were at the dissertation phase.

The gender and racial profile is similar to the nursing profession, which is female dominated and not diverse. Ninety percent of participants were female and $90 \%$ of participants self-identified themselves as white. Other self-identified race/ethnicity categories were African-American (4\%), Asian (4\%), Latino/a (4\%), and American-Indian (1\%). Eighty-five percent of participants were above the age of forty. Indeed, $51 \%$ of study participants were over the age of fifty.

The focus of this paper is to share the findings from three research questions of the study in which participants were invited to describe the quality of their doctoral student experience, to identify factors that enhance or detract from their student experience, and to share ideas about institutional practices that would improve their journey as doctoral student. Participants were allowed to avoid answering questions that made them uncomfortable so not all participants answered all survey questions. As such, numbers used in the following sections represent the responses to that particular survey item. 


\section{The Doctoral Student Experience}

Participants were invited to respond to the question, "If someone asked you what it is like to be a nurse faculty doctoral student, what would you tell them?" Two hundred and seventy-two participants $(\mathrm{N}=272)$ answered this item.

Twenty-eight percent of respondents $(n=76)$ described their student experience as positive using words such as exciting, rewarding, and worth it. Professional development occurred through growth as a scholar and by program content relevant and pertinent to their work. Forty-five percent of respondents $(n=122)$ chose a negative descriptor in describing their doctoral study choosing words such as difficult, stressful, frustrating and exhausting. The personal and emotional nature of doctoral work for some students is reflected in word choices such as lonely, painful, and frightening. The variety of replies demonstrates the personal nature of the doctoral student journey.

In answering this question, about five percent of participants $(n=13)$ offered advice or specific instructions for success as a nurse faculty doctoral student. It may be that the words "if someone asked you" in the survey item compelled them to share unsolicited advice as if communicating with prospective doctoral students. Table 1 summarizes advice offered to prospective doctoral students with regards to issues of time, planning, managing dual roles, seeking support, and reflection about initiating doctoral studies.

Seven percent of responses $(n=19)$ shared the difficulty of balancing the roles of academic career and doctoral students with phrases such as "almost impossible," "a struggle," and "very difficult". Fourteen percent of responses $(n=38)$ included the word challenge in describing the student experience, sometimes as the whole response or qualified such as "but fun", "but rewarding" or "but worth the effort".

Table 1: Advice from respondents to prospective doctoral students

\begin{tabular}{ll} 
Category & \multicolumn{1}{l}{ Respondent Statement } \\
Time & "Be prepared for an extraordinary busy time"; "Be realistic ... there is \\
(sic) only 24 hours in a day"; "Time management is your key to \\
success"; "They are indeed fortunate to have a job that allows that \\
degree of freedom of time" \\
"This has to be planned well in advance"; "I would recommend getting \\
the doctorate early so that you can take off two or three years, work \\
part time and take off" \\
"I would not recommend doing both [faculty position and doctoral \\
study] at same time"; "Do one or the other but not both"; " doing a \\
dual role does not come without its risks, primarily to your health and \\
stamina"; "I would tell them it's nearly impossible" \\
"Elicit support from your colleague/school in terms of workload, \\
assignments"; "... the expectation [for support]... should be there" \\
"It has to be something the person is personally and professionally \\
committed to do"; "Be sure it's what you want to do as it is difficult"; \\
"... it is very hectic and not necessarily rewarding. It depends on what \\
your reasons are for getting it"
\end{tabular}




\section{Enhancing Factors in the Student Experience}

Enhancing factors in the doctoral student experience, as listed in Table 2, include career goals, self-discipline, support of family, involvement with fellow students, positive academic selfconcept (student expectancy that they will be successful in academic endeavors), colleague support, and positive relationships with major advisors and faculty. Participants were asked to identify which of these factors enhanced their particular experience and to type a text response to elaborate on the value of a self-selected most enhancing factor. Two hundred and fifty responses ( $\mathrm{N}$ $=250$ ) were received to this survey item.

\section{Table 2: Single most enhancing factor} Item Response $\mathbf{N}=\mathbf{2 5 0}$

\begin{tabular}{lccc} 
Factor & n & Percent & Rank \\
Career goals & 57 & 22.8 & 1 \\
Self-discipline & 40 & 16.0 & 2 \\
The support of family & 39 & 15.6 & 3 \\
Involvement with other students & 32 & 12.8 & 4 \\
A positive academic self-concept & 29 & 11.6 & 5 \\
Support of colleagues & 22 & 8.8 & 6 \\
A positive relationship with advisor & 14 & 5.6 & 7 \\
Positive relationship with faculty & 12 & 4.8 & 8 \\
N/A (none apply to me) & 3 & 1.2 & 9 \\
The support of friends & 2 & 0.8 & 10 \\
\hline
\end{tabular}

Career goals emerged as the most frequently selected most enhancing factor; this factor was identified by close to twenty-three percent of respondents $(n=57)$. Participants stated that their place of employment expected the earned doctorate for job security, promotion, and tenure. Career goals served to provide the desire and focus to complete the degree and to justify the cost, commitment, and dedicated time to return to school. The investment in doctoral study reaped benefits in faculty role development and personal growth. Text descriptions of career goals as "the driving force," "without goals, I would flounder," and "need to keep your eye on the prize to get through the stress" reflect the meaning of career goals in the pursuit of the doctorate.

Self-discipline served as the key enhancing factor for sixteen percent of participants $(n=40)$. For these students, self-discipline served to improve chances for success and to cope with obstacles. The role of discipline and effort is reflected in statements such as "If it's to be, it's up to me." and "It would be chaos without self-discipline. It's that demanding."

Personal relationships with others - family, fellow students, and faculty colleagues - were described as valuable. About fifteen percent of responses $(n=39)$ identified their family as the single most enhancing factor in their student experience and described their involvement with assuming roles, helping with tasks, and providing understanding. Phrases such as "my lifeline," "have sustained me...many times I would have liked to walk away," and the "core of my life" capture the meaning of family relationships. Involvement with fellow students was primary to close to thirteen percent of nurse faculty doctoral students $(n=32)$ who described peers as intellectually stimulating and invaluable. Exchange of information, meeting new persons, and sharing common experiences were valuable in "having a cohort of others who are walking the same 
path." For nearly nine percent of participants $(n=22)$, faculty colleagues were key enhancers in offering empathy, guidance, and feedback. Faculty peers who have "traveled the path" and "validate why I am doing this" were seen as a special type of support. The participant reply, "most have gone through this process and have lived to tell the tale," is a telling comment about the doctoral student journey. Individual student academic self-concept (belief that they would be successful) was primary for approximately eleven percent $(n=29)$ of participants.

Student relationships with faculty and advisors were described as especially enhancing factors by about five percent of participants $(n=12 ; n=14)$, respectively. Program faculty were described as encouraging role models who shaped career and research goals. Students gained empowerment through genuine faculty efforts and mentorship. For some students, advisors that served as guides and mentors that "kept me going" and lessened the "formidable" obstacle of the dissertation were vital. Advisors also served as someone with whom students could talk as a friend and use as a sounding board for frustrations.

Of interest, one percent of responses $(n=3)$ stated that none of the factors related to their experience. This suggests a need for further research and identification of influential factors in the student experience.

\section{Detracting Factors in the Student Experience}

The literature guided the development of a list of detracting factors, as presented in Table 3, experienced by doctoral students. These were multiple life responsibilities, financial issues, difficult relationships with faculty or advisors, lack of academic self-discipline and negative academic self-concept (student expectancy that they will not be successful in academic endeavors). Participants were asked to identify which factors detracted from their particular experience and to type a text response to elaborate on the value of a self-selected most detracting factor. Two hundred and sixty five $(\mathrm{N}=265)$ were received for this survey item.

\section{Table 3: Single most detracting factor Item Response $\mathbf{N}=\mathbf{2 6 5}$}

$\begin{array}{lccc}\text { Factor } & \text { n } & \text { Percent } & \text { Rank } \\ \text { Multiple life responsibilities } & 166 & 62.6 & 1 \\ \text { Financial issues } & 44 & 16.6 & 2 \\ \text { N/A (none apply to me) } & 20 & 3.77 & 3 \\ \text { Difficult relationship with faculty } & 15 & 5.66 & 4 \\ \text { Difficult relationship with advisor } & 12 & 4.52 & 5 \\ \text { Lack of academic self-discipline } & 8 & 3.01 & 6\end{array}$

Sixty-two percent of participants $(\mathrm{n}=166)$ identified multiple role responsibilities as the single most detracting factor in their student experience. This factor held true across all demographic variables. Responses reflected efforts in trying to be successful at everything, frustration in having to make choices, and acknowledgement of the futility of trying to do too much. Demands limited time to engage in personal interests or to simply rest and reflect on life. A participant remark, "It is like living with no margins. That is, if my life were an $8.5 \times 11$ piece of paper, it would have 0.1 inch margins and a six point font," is an especially eloquent description of these concerns.

For sixteen percent of participants $(n=44)$, financial concerns were crucial and included tuition, travel, books, and child-care expenses. Money appeared to be a source of stress and worry for 
those meeting school obligations, raising families, and attempting to either pay off or avoid further debt.

Faculty and advisor relationships were key detractors for approximately five and four percent $(\mathrm{n}=$ $15, \mathrm{n}=12$ ) of students, respectively. Students expressed concerns about faculty and advisors in two key ways. The first described concern as to faculty availability, provision of feedback, and effective teaching. Some reported that program faculty were preoccupied with their own work and not attentive enough to students. A second issue was expressed as a perceived lack of caring or displays of power by faculty or advisors. Representative comments include, "a lack of nurturing of future nurse scholars...more of a hazing," and "you really can't say much to professors" express this student discomfort.

Three percent of participants $(\mathrm{n}=8)$ identified a lack of academic self-discipline as a key detracting factor. This issue played out in a personal tendency to procrastinate, negative beliefs as an impediment to success, and a reported likelihood that school obligations would "go to the back burner" when other responsibilities arose. Of interest, while 25 percent of participants had identified their academic self-concept (student expectancy that they will be successful in academic endeavors) as a general detracting factor in another survey item, none identified it as the single most detracting factor.

Of interest, seven percent of participants $(n=20)$ reported that none of the listed detracting factors applied to their experience. Further research is needed to refine our understanding of influential factors for doctoral students. The influence of factors may be more clearly discerned in a longitudinal study of a cohort of doctoral students.

\section{Recommendations for Supportive Program Practices}

Two hundred and thirty-five participants $(\mathrm{N}=235)$ made recommendations for supportive practices to doctoral programs. It is encouraging to note that close to fourteen percent of participants $(\mathrm{n}=32)$ had no recommendations for change. Other students offered constructive student-centered strategies for change.

Twenty-six percent of students $(n=61)$ made suggestions for efficiency in program scheduling and department processes such as more efficient program scheduling and department processes.

Recommendations included not changing course schedules abruptly, adapting to student needs with more flexible plans of study, and readily available faculty. Creative class scheduling such as weekend retreats, blocked classes, and concentrated sessions were suggested to serve needs of working doctoral students. Students also requested improved access to physical facilities through expanded library hours and flexible faculty office hours, as well as to campus resources such as financial aid and advisement being open at times amenable to their busy schedules. Web-based learning was endorsed as a supportive practice although participants also requested meaningful ways to engage face-to-face with student peers. Financial concerns were reiterated in requests for improved financial aid policies, availability of scholarships, tuition waivers, and increased availability of department assistantships.

Students seek advisors and faculty members who are experienced and accessible and able to "explain the ropes" of the doctoral education experience and faculty-student relationship. The need for emotional care is seen in statements such as, "Support those who endeavor to pursue a doctoral degree," "Acknowledge the many demands in our lives," and "Stop telling me "your family doesn't need you as much as you think they do!'”

Students expressed a need for information about college processes such as registration and scholarship access as well as orientation into the norms of doctoral education. One participant wrote, 
"it was taken for granted that I understood the process and expectations of my program ...you don't know what you don't know."

\section{Recommendations for Supportive Workplace Practices}

Two hundred and thirty five survey participants offered five areas for supportive workplace practices. The most common recommendation, made by nearly $31 \%$ of participants $(n=72)$, was a request for reduction in faculty workload or release time. Suggestions included reduced teaching obligations but fluid work timelines and flexible meeting schedules were also suggested as especially important near semester's end when both student and faculty workloads are heavy, during comprehensive exams, and during the dissertation phase of the program.

Financial concerns were raised by $24 \%$ of participants $(n=56)$ in answers that were typed in all uppercase, multiple exclamation points, or by repeated typing of the dollar (\$) sign. Requests for tuition support or improved reimbursement were suggested to allowing finishing school more quickly in exchange for a faculty position commitment to the institution post-graduation.

Just over 11 percent $(n=27)$ of responses made pleas for mentorship in the role of doctoral student and in developing research expertise. One participant noted that nurse faculty doctoral students are often junior faculty members who are assimilating into academic work role expectations and need support. This observation is consistent with the description by Schriner (2007) of the cultural dissonance experienced as nurses transition from clinical practice to academe.

\section{Discussion}

The findings of this study are consistent with previous research documenting the unique rewards and challenges of doctoral study. The motivation of individuals to gain personal growth and career development through ongoing education is admirable. Returning to pursue the terminal degree occurs in the context of the student's whole life. The reality of multiple life obligations for these students emerged strongly in this study. Nurse faculty who make the decision to earn the doctorate are typically older than other graduate students and fully immersed in the demands of career, community life, and family responsibilities. As such, careful planning is needed to achieve academic success but also to cope with the impact of these multiple demands. Many of the participants in this study were well on their way in their doctoral program. Based on the findings of this study, beginning and continuing doctoral students need a reminder that, while rewarding, the doctoral student journey is neither short nor easy. Strategies that work at one point along the trajectory may fail at another time. The need to adapt and adjust with the ebb and flow of a plan of study is important. Thoughtful consideration is needed to reflect upon enhancing and detracting factors as they pertain to the life of the student. Adjustments must be made that are suitable to the individual student and work toward a goal of maintenance of wellness. The proactive creation of support systems and the development of realistic goals are imperative in finding success and life satisfaction. In particular, given the age of many nurse faculty doctoral students, the likelihood of caregiver responsibilities to minor children and others present a very real challenge in the availability of time and energy.

Improving the ranks of doctoral prepared nurse educators is crucial to the advancement of nursing education and the profession. Research findings on registered nurses in a baccalaureate program, led Ritchie, Evans, MacNeil and Micsinszki to contend that educators need to go beyond ensuring student "survival" in creating educational programs that focus on student well-being, personal, and professional development $(2005$, p. 10). This finding also holds true for graduate education and the development of doctoral prepared nurse faculty. It is in our collective best interest to promote the timely and satisfying completion of the doctoral degree by our nursing colleagues. The development of nursing education and doctoral program cultures that encourage, mentor, and 
support professional colleagues can serve to heighten doctoral student satisfaction and a commitment to an academic career.

An appreciation of the complexities of the student experience and a critical examination of factors affecting student satisfaction and success are foundational to the design and administration of quality doctoral education. Doctoral program faculty and administrators must create a supportive environment while also clearly communicating the demands and expectations of doctoral study. In a competitive market, institutions that can demonstrate a student-centered approach hold a recruitment advantage and can take pride in the delivery of quality services and education. Doctoral students also have an obligation to be curious and proactive in selecting a program of study that best suits their professional and personal needs.

The author suggests that although this study surveyed nurse faculty engaged in graduate study, the findings are relevant for doctoral program faculty and administrators in other disciplines, in particular other health professions in which professional doctorate programs are growing at a rapid pace. The findings presented in this paper represent the perspective of study participants and cannot be generalized to other student populations. Further research on this topic is warranted. A deeper understanding of the student experience and appreciation of changing student needs might be gained through longitudinal studies of student cohorts from matriculation to program completion.

\section{Conclusion}

Participants in this study identified the meaning of their doctoral student journey, shared their perspective on aids and deterrents, and made constructive recommendations for supportive practices. Their responses provide insight into factors that affect the student experience and articulate the influence of others on their interpretation of their experience. Cohen (1999) suggested that historically university faculty and researchers have operated within the silo of their particular discipline and have created a competitive research environment. Multiple departments and personnel in the higher education setting share an interest in the delivery of quality educational programs and positive student outcomes. Cross-discipline research about doctoral students, collaboration in the examination of institutional culture, and the collective development of student supportive practices is warranted.

\section{References}

Ali, A. \& Kohun, F. (2007). Dealing with social isolation to minimize doctoral attrition. International Journal of Doctoral Studies, 2, 33-49. Retrieved from http://ijds.org/Volume2/IJDSv2p033049Ali28.pdf

American Association of Colleges of Nursing. (2003). Faculty shortages in baccalaureate and graduate programs in nursing: Scope of the problem and strategies for expanding the supply. Washington, DC: American Association of Colleges of Nursing. Retrieved September 1, 2008 from http://www.aacn.nche.edu/Publications/WhitePapers/FacultyShortages.htm

American Association of Colleges of Nursing. (2005, March). New data confirms shortage of nursing school faculty hinders efforts to address nation's nursing shortage. Retrieved September 1, 2008 from http://www.aacn.nche.edu/Media/NewsReleases/2005/Enrollments05.htm

American Association of University Professors (1987). Statement on professional ethics. Washington, D.C.: American Association of University Professors. Retrieved January 3, 2006, from http://www.aaup.org/statements/Redbook/statements/Redbook/Rbethics.htm

American Association of University Professors. (2001). Statement of principles on family responsibilities and academic work. Washington, D.C.: American Association of University Professors. Retrieved September 1, 2008 from http://www.aaup/org/AAUP/pubsres/policydocs/contents/workfam-stmt.htm 
Anderson, M., \& Swazey, J. (1998). Reflections on the graduate student experience. In M. Anderson (Ed.), New directions for higher education: No. 101. The experience of being in graduate school: An exploration (pp. 3-13). San Francisco: Jossey-Bass.

Appel, M., \& Dahlgren, L. (2003). Swedish doctoral students' experiences on their journey toward a PhD: Obstacles and opportunities inside and outside the academic building. Scandinavian Journal of Education Research, 47, 89-110.

Austin, A. E. (2002). Creating a bridge to the future: Preparing new faculty to face changing expectations in a shifting context. Review of Higher Education, 26, 119-144.

Blair, K., Dennehy, P., \& White, P. (2005). Nurse practitioner faculty practice: An expectation of professionalism. Washington, D.C.: National Organization of Nurse Practitioner Faculties. Retrieved September 1, 2008 from http://www.nonpf.com/FPStatement2005Final.pdf

Boyer, E. (1990). Scholarship reconsidered: Priorities of the professoriate. Princeton, NJ: The Carnegie Foundation for the Advancement of Teaching.

Canadian Nurses Association. (2006). Toward 2020: Visions for nursing. Retrieved September 1, 2008 from http://www.cna-nurses.ca/CNA/documents/pdf/publicatiions/Toward-2020-e.pdf

Cohen, E. (1999). From ugly duckling to swan: Reconceptualizing information systems as a field of the discipline informing science. Journal of Computing and Information Technology, 7(3), 213-219.

Cole, P., \& Curtis, J. (2004). Academic work and family responsibility: A balancing act. Retrieved September 1,2008 from http://sciencecareers.sciencemag.org/career/magazine/previous issues/articles/2004_01_16/noDOI.850 $\underline{1657169899476988}$

Colombaro, G. (1998). The process of scholarly maturing: Experiences which enabled five female nurses to complete their doctorates. DissertationAbstracts International, 59(09), 4726B. (UMI No. 9908266)

Council of Graduate Schools. (2008). PhD Completion Project: Institutional Factors. Retrieved April 20, 2008 from http://www.phdcompletion.org/information/factors.asp

Curtis, J. (2004). Balancing work and family for faculty: Why it's important. Academe, 90(6), 21-23.

Dillman, D. (2000). Mail and internet surveys: The tailored design method ( $2^{\text {nd }}$ ed.). New York: John Wiley and Sons.

Fitzpatrick, J. (2003, First quarter). The case for the clinical doctorate in nursing. Reflections on Nursing Leadership, 8-9, 37.

Fawcett, J., \& Buhle, E. (1995). Using the internet for data collection: An innovative electronic strategy. Computer Nursing, 13, 273-279.

Golde, C. (1998). Beginning graduate school: Explaining first year doctoral attrition. In M. Anderson (Ed.), New directions for higher education: No. 101. The experience of being in graduate school: An exploration (pp. 55-64). San Francisco: Jossey-Bass.

Golde, C. (2006). Preparing stewards of the discipline. In C. Golde \& G. Walker (Eds.). Envisioning the Future of doctoral education: Preparing stewards of the discipline. (pp. 3-22). San-Francisco: JosseyBass.

Gormley, D. (2003) Factors affecting job satisfaction in nurse faculty: A meta-analysis. Journal of Nursing Education, 43(4), 174-178.

Heinrich, K. (2000). The passionate scholar: A mid-life, woman doctoral student's quest for voice. International Journal of Qualitative Studies in Education, 13, 63-83.

Heinrich, K., Rogers, A., Haley, R., \& Taylor, A. (1997). Mid-life women doctoral students rediscover "voice" in a community of scholarly caring. Journal of Professional Nursing, 13, 352-364.

Houtkoop-Steenstra, H. (2000). Interaction and the standardized survey interview: The living questionnaire. Cambridge: Cambridge University Press. 
Jarnagin, T. (2005). The meaning of the experience of doctoral course work for midlife female nursing faculty. Dissertation Abstracts International, 66 (02), 813B. (UMI No. 3164916).

Kenty, J. (1995). Matching social support and stress: An investigative study of female faculty pursuing doctoral study. Dissertation Abstracts International, 56 (10), 5404B. (UMI No. 9605487).

Kerlin, S. (1995). Surviving the doctoral years: Critical perspective [Electronic version]. Education Policy Analysis Archives, 3(17), 1-37. Retrieved December 2, 2005, from http://epaa.asu.edu/epaa/v3n17.html

Lee, C. (2009). Multi-tasking as doctoral student, faculty, caregiver. Women in Higher Education 18(5), 22-23.

Mason, M., \& Goulden, M. (2004). Do babies matter (Part II): Closing the baby gap. Academe, 90(6), 1015.

International Council of Nurses. (2006). The global nursing shortage: Priority areas for intervention. Retrieved September 1, 2008 from http://www.icn.ch/global/report2006.pdf

National Center for Education Statistics. (2004). Digest of Education Statistics 2004. Chapter 3: Postsecondary Education. Retrieved April 6, 2006, from http://nces.ed.gov/programs//digest/d04/tables/dt04_214.asp

National Organization of Nurse Practitioner Faculties. (2005). Faculty practice promotion and tenure Retrieved September 1, 2008 from http://www.nonpf.com/NONPF/FacultyPracticeResourceCenter/FPNONPFstatement.htm

Pope, C., Ziebland, S., \& Mays, N. (2000). Qualitative research in health care: Analysing qualitative data [Electronic version]. British Medical Journal, 320, 114-116. Retrieved September 1, 2008, from http://bmj.bmjjournals.com/cgi/reprint/320/7227/114.pdf

Ritchie, L., Evans, M., MacNeil, M. \& Micsinski, S. (2005). “Surviving”: Registered nurses' experiences in a baccalaureate nursing program. International Journal of Nursing Education Scholarship, 2(1), Article 15, 1- 10. Retrieved September 1, 2008 from http://www.bepress.com/ijnes/vol2/iss1/art15/

Schriner, C. (2007). The influence of culture on clinical nurses transitioning into the faculty role. Nursing Education Perspectives, 28(3), 145-150.

Seagram, B., Gould, J., \& Pyke, S. (1998). An investigation of gender and other variables on time to completion of doctoral degrees. Research in Higher Education, 39, 319-335.

Siler, B., \& Kleiner, C. (2001). Novice faculty: Encountering expectations in academia. Journal of Nursing Education, 40, 397-403.

Sweitzer, V. (2009). Toward a theory of doctoral student professional identity development: A developmental theory approach. Journal of Higher Education, 80(1), 1-33.

Ward, K., \& Wolf-Wendel, L. (2004). Fear factor: How safe is it to make time for family? Academe, 90(6), 28-31.

Weidman, J., \& Stein, A. (2003). Socialization of doctoral students to academic norms. Research in Higher Education, 44, 641-656.

Weidman, J., Twale, D. \& Stein. A. (2001). Socialization of graduate and professional students in higher education: A perilous passage? (ASHE-ERIC Higher Education Report, No. 3). San-Francisco: Jossey-Bass.

Young, P. (1999). Joining the academic community: The lived experiences of new teachers in nursing education. Dissertation Abstracts International, 61 (02), 787B. (UMI No.9956274). 


\section{Appendix: Nurse Faculty Doctoral Student Survey}

1. If someone asked you what it is like to be a nurse faculty member who is also a doctoral student, what would you tell them? Please click in the text box to type your answer.

2. Professional career goals are described as a factor that enhances the experience of doctoral students. Is this your experience?

o Yes

$\circ$ No

$\circ \mathrm{N} / \mathrm{A}$

3. The support of professional colleagues has been identified as a factor that enhances the experience of doctoral students. Is this your experience?

$\circ$ Yes

$\circ$ No

$\circ \mathrm{N} / \mathrm{A}$

4. A positive relationship with doctoral program faculty has been described as a factor that enhances the experience of doctoral students. Is this your experience?

$\circ$ Yes

$\circ$ No

$\circ \mathrm{N} / \mathrm{A}$

5. The support of family has been described as a factor that enhances the experience of some doctoral students. Is this your experience?

$\circ$ Yes

○ No

$\circ \mathrm{N} / \mathrm{A}$

6. Self-discipline has been described as a factor that enhances the experience of some doctoral students. Is this your experience?

$\circ$ Yes

$\circ$ No

$\circ \mathrm{N} / \mathrm{A}$

7. Involvement with fellow doctoral students has been described as a factor that enhances the experience of doctoral students. Is this your experience?
$\circ$ Yes
$\circ$ No
$\circ \mathrm{N} / \mathrm{A}$

8. A positive relationship with their doctoral program major advisor has been described as a factor that enhances the experience of doctoral students. Is this your experience?

- Yes

- No

○ N/A 
9. The support of friends has been described as a factor that enhances the experience of doctoral students. Is this your experience?

$\circ$ Yes

$\circ$ No

$\circ \mathrm{N} / \mathrm{A}$

10. A positive academic self-concept (belief that you will be successful) has been described as a factor that enhances the experience of doctoral students. Is this your experience?

$\circ$ Yes

$\circ$ No

$\circ \mathrm{N} / \mathrm{A}$

11. From the following list of enhancing factors, please bubble in the SINGLE factor most influential as an enhancing factor in your doctoral student experience.

o Professional career goals

- The support of professional colleagues

$\circ$ A positive relationship with doctoral program faculty

$\circ$ The support of family

○ Self-discipline

o Involvement with fellow doctoral students

- A positive relationship with doctoral program major advisor

$\circ$ The support of friends

$\circ$ A positive academic self-concept

12. In the previous item, you selected a single most enhancing factor in your doctoral student experience. Please click in the text box to describe why you chose that factor.

13. Please type into the text box any other factors that you would identify as enhancing your experience of being a doctoral student.

14. The demands of multiple life responsibilities have been described as a factor that detracts from the experience of doctoral students. Is this your experience?

$\circ$ Yes

$\circ$ No

$\circ \mathrm{N} / \mathrm{A}$

15. Difficult relationships with doctoral program faculty have been described as a factor that detracts from the experience of doctoral students. Is this your experience?

$\circ$ Yes

$\circ$ No

$\circ \mathrm{N} / \mathrm{A}$

16. A lack of self-discipline has been described as a factor that detracts from the experience of doctoral students. Is this your experience?

- Yes

- No

○ N/A 
17. A negative academic self-concept (belief that you will not be successful) has been described as a factor that detracts from the experience of doctoral students. Is this your experience?

$\circ$ Yes

$\circ$ No

$\circ \mathrm{N} / \mathrm{A}$

18. A difficult relationship with their major advisor has been identified as a factor that detracts from the experience of doctoral students. Is this your experience?

$\circ$ Yes

$\circ$ No

$\circ \mathrm{N} / \mathrm{A}$

19. Financial issues has been described as a factor that detracts from the experience of doctoral students. Is this your experience?

$\circ$ Yes

$\circ$ No

$\circ \mathrm{N} / \mathrm{A}$

20. From the following list of detracting factors, please bubble in the SINGLE most detracting factor in your doctoral student experience.

oMultiple life responsibilities

oDifficult relationships with doctoral program faculty

$\circ$ A lack of self-discipline

$\circ$ A negative academic self-concept

$\circ$ A difficult relationship with major advisor

oFinancial issues

$\circ \mathrm{N} / \mathrm{A}$ - none of these detracting factors apply to me

21. In the previous item, you selected a single most detracting factor in your doctoral student experience. Please click in the text box to describe why you chose that factor.

22. Please click in the text box to describe any other factors that you would identify as detracting from your experience as a doctoral student.

23. Do you have caregiver responsibilities for children under the age of eighteen?

$\circ$ Yes

$\circ$ No

24. If you answered yes to the previous item, please click in the text box to describe how caregiver responsibilities for children intersects with your role of being a nurse faculty doctoral student. If you answered no to the previous item, please move to the next item.

25. Do you have caregiver responsibilities for persons other than children under the age of eighteen?

$\circ$ Yes

$\circ$ No

26. If you answered yes to the previous item, please click in the text box to describe how caregiver responsibilities for others intersect with your role of being a nurse faculty doctoral student. If you answered no to the previous item, please move to the next item. 
27. Please click inside the text box and type your recommendations for the doctoral program in which you are enrolled to support the experience of nurse faculty doctoral students.

28. Please click inside the text box and type your recommendations for the institution in which you are employed to support the experience of nurse faculty doctoral students.

29. My workplace provides release time to faculty enrolled as doctoral students from responsibilities in: (Choose all that apply)

$\begin{array}{ll}\text { Teaching } & \circ \\ \text { Scholarship } & \circ \\ \text { Service } & \circ \\ \text { Practice } & \circ\end{array}$

30. My workplace provides tuition assistance for my doctoral program.

$\circ$ Yes

$\circ$ No

31. My workplace provides an opportunity to extend expected promotion timelines in order to complete my doctoral degree program.

$\circ$ Yes $\circ$ No $\circ \mathrm{N} / \mathrm{A}$

32. Is there anything else about your experience as a nurse faculty doctoral student that you would like to share?

$\circ$ Yes。 No

Please click in the text box to type your response

The last section of the survey asks for demographic information. Please bubble in the item that best describes you.

33. Years as a nurse: $\circ 0-5 \quad \circ 6-10 \quad \circ 11-19 \quad \circ 20+$

34. Years as a faculty member: $\circ 0-5 \quad \circ 6-10 \quad \circ 11-19 \quad \circ 20+$

35. Full-time faculty appointment: $\circ$ Yes $\circ$ No

36. Tenure track position $\circ$ Yes $\circ$ No

37. Institution where employed is $\circ$ Public $\circ$ Private

38. Institution where employed is accredited $\circ$ Yes $\circ$ No

39. Sex o Female oMale

40. Age: $\circ 25-29 \quad \circ 30-39 \quad \circ 40-49 \quad \circ 50+$

41. Race/Ethnicity (Choose all that apply)

$\circ$ White $\circ$ African-American $\circ$ Asian $\circ$ Latino/a $\circ$ American-Indian $\circ$ Other

42. Marital status: $\circ$ Married $\circ$ Single $\circ$ Divorced $\circ$ Domestic partner relationship

43. Parent of children less than eighteen years of age $\circ$ Yes $\circ$ No 
44. Major area of study: $\circ$ Nursing $\circ$ Other

45. Full-time student $\circ$ Yes $\circ$ No

46. Does your program have a residency requirement? $\circ$ Yes $\circ$ No

47. Does your program have a qualifying/candidacy exam requirement?

$\circ$ Yes $\circ$ No

48. Dissertation in progress $\circ$ Yes $\circ$ No $\circ \mathrm{N} / \mathrm{A}$

49. Majority of my program is $\circ$ On-campus $\circ$ Distance Education

50. Percent of program completed $\circ 1-25 \% \circ 26-50 \% \circ 51-74 \% \circ 75-100 \%$

51. Estimated time to graduation $\bigcirc$ Less than 12 months

$\circ 12$ months to 23 months

o 24 months to 35 months

○ 36 months to 5 years

(C) Carolyn J. Lee / 2009

$\circ$ More than 5 years

\section{Biography}

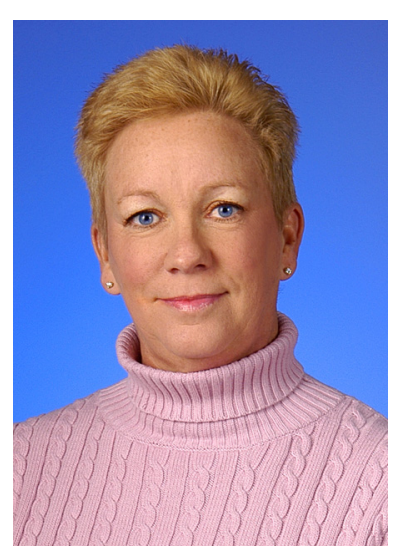

Carolyn (Carrie) Lee, $\mathrm{PhD}, \mathrm{CNE}, \mathrm{RN}$ is an Associate Professor of Nursing at The University of Toledo, Toledo, Ohio, USA. Her clinical specialty is women's health.

She teaches women's health clinical nursing as well as courses in nursing education, family/culture and professional role socialization. She has published on a variety of topics including women's birth stories, academic help-seeking, culturally congruent care, and the experience of women doctoral students. Research interests include women's birth stories and the experience of doctoral students. 